\title{
PENGARUH SIKAP, NORMA SUBYEKTIF, DAN KONTROL PERILAKU PADA PENGUNGKAPAN TANGGUNG JAWAB SOSIAL
}

\author{
Nurofik \\ Sekolah Tinggi Ilmu Ekonomi YKPN Yogyakarta \\ e-mail: nurofik_stieykpn@yahoo.com
}

\begin{abstract}
This paper investigates decisions to disclose CorporateSocial Responsibility (CSR) at the level of individual decision maker by applying the theory of planned behavior. 138 Indonesia Stock Exchange (IDX) listed companies' annual reports for 2007 and 2008 financial years are examined. Questionnaires were sent to these companies. The findings of this research indicate that CSR disclosure is influenced by the intentions to disclose the CSR and perceived behavioral control over the disclosure of CSR. The intentions to disclose the CSR are significantly influenced by attitude towards to CSR disclosure, subjective norms of the CSR disclosure, and perceived behavioral control over the CSR disclosure.
\end{abstract}

Keywords: corporate social responsibility disclosure, behavioral intentions, attitude towards the behavior, subjective norms, perceived behavioral control.

\begin{abstract}
Abstrak
Paper ini meneliti keputusan untuk mengungkapkan tanggung jawab sosial perusahaan (TSP) pada tingkat pengambil keputusan individual dengan mengaplikasikan teori perilaku rencanaan. 138 perusaan yang terdaftar di Bursa Efek Indonesia (BEI) diteliti laporan tahunannya untuk periode tahun keuangan 2007 dan 2008. Kuesioner dikirimkan juga ke perusahaan-perusahaan tersebut. Hasil penelitian ini mengindikasikan bahwa pengungkapan TSP dipengaruhi oleh niat untuk mengungkapkan TSP dan kontrol perilaku persepsian terhadap pengungkapan TSP. Niat untuk mengungkapan TSP dipengaruhi secara signifikan oleh sikap terhadap pengungkapan TSP, norma subyektif pengungkapan TSP, dan kontrol perilaku persepsian terhadap pengungkapan TSP.
\end{abstract}

Kata kunci: pengungkapan tanggung jawab sosial perusahaan, niat perilaku, sikap terhadap perilaku, norma subyektif, kontrol perilaku persepsian.

\section{PENDAHULUAN}

Bentuk paling sederhana dari akuntansi pertanggungjawaban sosial perusahaan adalah pengungkapan tentang praktik-praktik tanggungjawab sosial berusahaan (untuk selanjutnya disingkat TSP). Selain sebagai metode untuk mengukur keterlibatan sosial perusahaan (Abbott dan Monsen 1979), pengungkapan TSP merupakan upaya perusahaan untuk menginformasikan kepada pihak eksternal bahwa perusahaan responsif terhadap kepentingan stakeholders (Mangos dan Lewis 1995), dan untuk menunjukkan tingkat akuntabilitas dan transparansi informasi kepada masyarakat (Gray 1992).
Penelitian tentang pengungkapan TSP telah banyak dilakukan. Namun, penelitianpenelitian tersebut fokus pada perusahaan sebagai unit analisis dan pada umumnya dilakkan menggunakan perspektif teori kegunaan keputusan (misalnya Epstein dan Freedman 1994), teori ekonomi (Belkaoui dan Karpik 1989), teori legitimasi (misalnya Patten 2002), dan teori stakeholder (Kent dan Chan 2003).

Sifat sukarela dalam pengungkapan TSP menyebabkan perbedaan lingkup dan kedalaman pengungkapan TSP antarperusahaan. Oleh karena itu, patut diduga, pengungkapan TSP dipengaruhi oleh motivasi manajer per- 
usahaan. Penelitian O'Dwyer (2002) menunjukkan hal tersebut, yaitu perusahaan hanya membuat sedikit pengungkapan informasi negatif tentang lingkungan. Selain itu, penelitian Wiseman (1982) menunjukkan perusahaan tidak secara lengkap membuat pengungkapan lingkungan dan tidak berhubungan dengan kinerja lingkungan yang sesungguhnya dicapai. Berbagai penelitian ini secara eksplisit menunjukkan bahwa analisis terhadap variabel psikologi manajer akan memiliki arti penting untuk menjelaskan pengungkapan TSP.

Penelitian ini menginvestigasi pengaruh variabel-variabel perilaku terhadap keputusan untuk mengungkapkan TSP pada level pengambil keputusan individual. Tujuannya untuk menguji pengaruh faktor-faktor keperilakuan manajer terhadap pengungkapan TSP. Untuk mencapai tujuan tersebut, pada penelitian ini diuji pengaruh faktor-faktor situasional dan personal manajer terhadap keputusan pengungkapan TSP. Basis teori yang digunakan adalah teori perilaku rencanaan (theory of planned behavior) yang dikembangkan oleh Ajzen (1985 1991).

\section{TINJAUAN PUSTAKA DAN PERUMUSAN HIPOTESIS}

Teori perilaku rencanaan (untuk selanjutnya disebut TPR) merupakan perluasan dari teori tindakan bernalar (theory of reasoned action) yang dikembangkan oleh Fishbein dan Ajzen (1975). ${ }^{1}$ TPR mengakomodasi satu variabel baru yang tidak terdapat pada teori tindakan bernalar (TTB). Variabel tersebut adalah kontrol perilaku persepsian (perceived behavioral control).

Asumsi dalam TPR — juga merupakan asumsi dalam TTB - adalah orang memilih serangkaian tindakannya secara rasional. Menurut TTB/TPR, perilaku diyakini sebagai hasil dari niat keperilakuan (behavioral inten-

\footnotetext{
${ }^{1}$ Uraian lengkap tentang teori tindakan bernalar dapat dilihat pada Nurofik. 2013."Pengaruh Sikap dan Norma Subyektif pada Pengungkapan Tanggung Jawab Sosial Perusahaan." Jurnal Akuntansi dan Manajemen. Vol. 24, No. 1, April 2013: 23-33.
}

tions). Niat didefinisi sebagai probabilitas subjektif individu dalam menentukan pilihan atas berbagai alternatif keperilakuan. Selanjutnya, menurut TTB/TPR, niat individu untuk mehk ukan perilaku ditentukan oleh tiga faktor yang masing-masing bersifat independen (Ajzen 1985; 1991). Faktor pertama adalah 'sikap terhadap perilaku (attitude towards the behavior).' Sikap terhadap perilaku merupakan konstruk yang menggabungkan keyakinan seseorang tentang kemungkinan outcome tertentu dari hasil perilaku (disebut juga sebagai keyakinan perilaku) dan evaluasi secara menyeluruh oleh seseorang atas outcome tersebut. Menurut TTB/TPR, individu yang meyakini pelaksanaan perilaku tertentu akan menyebabkan outcome positif, maka ia akan mempunyai sikap yang mendukung pelaksanaan perilaku tersebut.

Faktor kedua adalah 'norma subyektif (subjective norm).' Norma subyektif menunjukkan keyakinan individu terhadap tekanan sosial untuk melakukan atau tidak melakukan perilaku (disebut juga sebagai keyakinan normatif). Norma subyektif merupakan konstruk yang menggabungkan keyakinan individu terhadap referents tertentu dan motivasi seseorang untuk patuh kepada referentsnya. ${ }^{2}$ Semakin tinggi keyakinan seseorang bahwa referennya menghendaki suatu perilaku tertentu dan semakin tinggi kepatuhan orang tersebut terhadap referennya, maka semakin tinggi kecenderungan orang tersebut untuk melakukan perilaku tertentu.

Faktor ketiga dan merupakan variabel yang ditambahkan dari teori tindakan bernalar adalah 'kontrol perilaku persepsian (perceived behavioral control).' Kontrol perilaku persepsian didefinisikan sebagai keyakinan seseorang tentang tingkat kesulitan/kemudahan dalam melakukan perilaku (disebut juga sebagai keyakinan kontrol) (Ajzen 1991) atau tingkat kewenangan yang diberikan kepada seseorang untuk melaksanakan perilaku (Carpenter dan Reimers 2005). Semakin tinggi tingkat kewenangan yang dimiliki seseorang

\footnotetext{
${ }^{2}$ Referent merupakan individu atau kelompok orang yang dipandang penting dan opininya mempengaruhi proses keputusan subyek.
} 
untuk melakukan perilaku tertentu, maka semakin mudah bagi orang tersebut untuk meh kukannya.

Beberapa penelitian akuntansi dengan perspektif teori TTB dan TPR telah dilakukan. Weldman (2002) meneliti keputusan untuk mengungkapkan kewajiban lingkungan pada level pembuat keputusan individual menggunakan basis TPR. Hipotesis penelitiannya adalah niat untuk mengungkapkan kewajiban lingkungan dipengaruhi oleh sikap, norma subyektif, kontrol perilaku persepsian, dan persepsi atas kewajiban moral. Subyek penelitianya adalah para eksekutif finansial yang tercatat sebagai anggota Institute of Management Accountants. Sampel dipilih secara random. Dari penelitian tersebut Weldman (2002) menemukan, antara lain: (1) pengungkapan kewajiban lingkungan dipengaruhi oleh variabel individual (sikap individu terhadap perilaku) dan sosial (norma subyektif), (2) kontrol perilaku persepsian mempunyai pengaruh signifikan terhadap niat untuk mengungkapkan kewajiban lingkungan, dan (3) norma subyektif mempunyai peran yang signifikan dalam mempengaruhi keputusan untuk mengungkapkan kewajiban lingkungan.

Carpenter dan Reimers (2005) melakukan penelitian eksperimen untuk menerapkan teori perilaku rencanaan terhadap keputusan pelaporan keuangan oleh manajer perusahaan dalam konteks etika, yaitu kecenderungan untuk berperilaku curang dalam bentuk earnings management pada pelaporan keuangan. Hasil penelitian mereka membuktikan teori perilaku rencanaan merupakan teori yang robust untuk diterapkan dalam konteks pelaporan keuangan dan berguna untuk memprediksi keputusan pelaporan keuangan oleh manajer, terutama untuk sikap dan normanorma sosial.

Pengaplikasian TPR dalam konteks pengungkapan TSP berarti pengungkapan TSP dipengaruhi oleh niat mengungkapkan TSP dan kontrol perilaku persepsian atas pengungkapan TSP. Niat mengungkapkan TSP merupakan fungsi dari tiga faktor, yaitu (1) keyakinan manajer terhadap konsekuensi (outcome) pengungkapan TSP yang kemudian memben- tuk sikap terhadap pengungkapan TSP, (2) keyakinan manajer terhadap tekanan sosial untuk melakukan atau tidak melakukan pengungkapan TSP yang kemudian membentuk norma subyektif atas pengungkapan TSP, dan (3) keyakinan manajer untuk mengontrol pengungkapan TSP.

Spesifik untuk pengungkapan TSP, berbasis pada TTB, Nurofik (2013) meneliti pengaruh sikap dan norma subyektif pada pengungkapan TSP. Hasil penelitian menunjukkan (1) sikap dan norma subyektif berpengaruh secara signifikan pada niat untuk mengungkapan TSP, dan (2) niat untuk meng ungkapkan TSP berpengaruh secara signifikan pada pengungkapan TSP.

Berdasarkan uraian yang telah dipaparkan, penelitian-penelitian yang ada telah mengonfirmasi kaidah TTB/TPR yang menyatakan sikap seseorang terhadap perilaku mempengaruhi niatnya untuk melakukan perilaku. Oleh karena itu, pada penelitian ini dihipotesiskan sebagai berikut:

H1: Sikap manajer atas pengungkapan TSP berpengaruh positif terhadap niatnya untuk mengungkapkan TSP.

Kaidah kedua dari TTB/TPR menyatakan semakin kuat keyakinan seseorang terhadap tekanan sosial untuk melakukan perilaku, maka semakin kuat niat seseorang tersebut untuk melakukan perilaku. Penelitian oleh Weldman (2002), Carpenter dan Reimers (2005), dan Nurofik (2013) telah mengonfirmasi kaidah teori perilaku rencanaan yang menyatakan norma subyektif mempengaruhi niat seseorang untuk melakukan perilaku. Oleh karena itu, pada penelitian ini dihipotesiskansebagai berikut:

H2: Norma-norma subyektif manajer atas pengungkapan TSP berpengaruh positif terhadap niatnya untuk mengungkapkan TSP.

Kaidah ketiga dari teori perilaku rencanaan menyatakan semakin kuat kontrol perilaku persepsian seseorang, maka semakin kuat niat seseorang tersebut untuk melakukan perilaku. Penelitian Weldman (2002) menun- 
jukkan kontrol perilaku persepsian mempunyai pengaruh signifikan terhadap niat eksekutif keuangan untuk mengungkapkan kewajiban lingkungan. Oleh karena itu, pada penelitian ini dihipotesiskan sebagai berikut:

H3: Kontrol perilaku persepsian manajer atas pengungkapan TSP berpengaruh positif terhadap niatnya untuk mengungkapkan TSP.

Menurut TPR, niat perilaku bersamasama dengan kontrol perilaku persepsian dapat digunakan secara langsung untuk memprediksi kinerja perilaku. Kaidah umum teori perilaku rencanaan adalah semakin kuat niat seorang individu untuk terlibat dalam suatu perilaku dan semakin kuat kontrol perilaku persepsian, maka semakin besar kemungkinan akan terjadi kinerja perilaku. Sebagai contoh, sekalipun dua individu mempunyai niat yang sama kuat untuk belajar bermain ski, dan keduanya berusaha keras melakukan hal tersebut, namun individu yang meyakini bahwa dia dapat menguasai aktivitas tersebut akan mempunyai kemungkinan lebih gigih untuk bermain ski daripada individu yang meragukan kemampuan dirinya (Ajzen 1991).

Bukti empiris tentang pengaruh niat perilaku terhadap kinerja perilaku telah banyak dilakukan. Dalam penelitian tentang perilaku pembayar pajak, Hanno dan Violette (1996) menemukan korelasi yang kuat (0.58) antara niat untuk mematuhi regulasi perpajakan dan perilakunya. Dalam review terhadap 87 studi yang menggunakan teori tindakan beralasan, Sheppard et al. (1988) menemukan korelasi yang kuat (0.53) antara niat untuk berperilaku dengan perilaku itu sendiri (dalam Weldman 2002). Nurofik (2013) telah membuktikan niat untuk mengungkapkan TSP berpengaruh positif terhadap pengungkapan TSP. Oleh karena itu, dalam penelitian ini dihipotesiskan:

H4: Niat manajer untuk mengungkapkan TSP berpengaruh positif terhadap pengungkapan TSP.

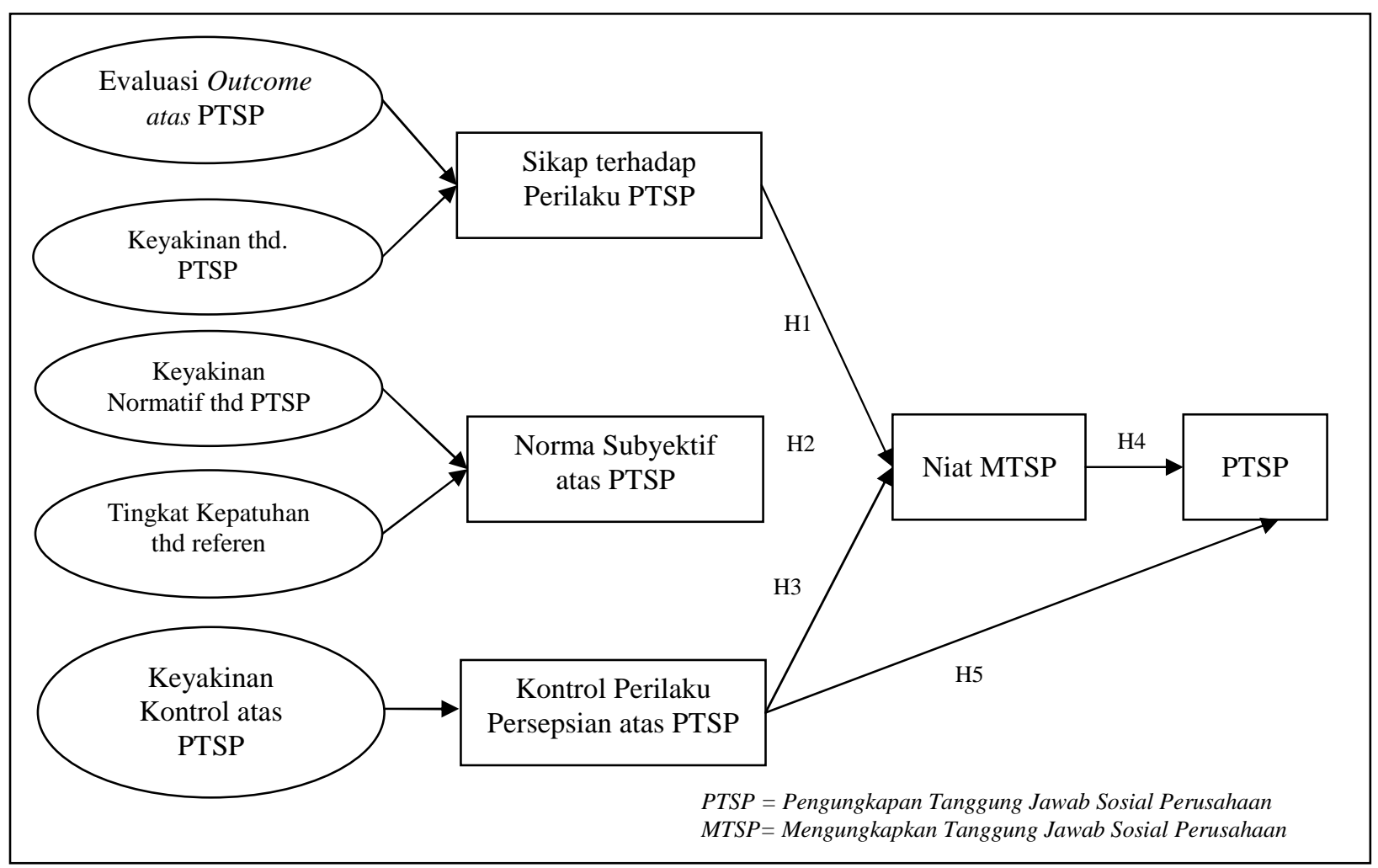

Gambar 1: Rerangka Penelitian 
Menurut Ajzen (1991), kinerja dari suatu perilaku merupakan fungsi gabungan dari niat dan kontrol perilaku persepsian. Selanjutnya, Ajzen (1991) menyatakan konstruk kontrol perilaku persepsian kompatibel dengan self-efficacy. Oleh karena penelitian-penelitian dengan rerangka self-efficacy menunjukkan bahwa perilaku masyarakat sangat dipengaruhi oleh keyakinannya tentang kemampuan mereka untuk melakukan perilaku, maka berarti perilaku dipengaruhi juga oleh kontrol perilaku persepsian (Ajzen 1991).

Beberapa penelitian telah berusaha memprediksi perilaku dengan mengombinasikan niat dan kontrol perilaku persepsian. Telaah oleh Ajzen (1991) terhadap beberapa penelitian tersebut menunjukkan niat dan kontrol perilaku persepsian berkorelasi cukup baik dengan kinerja perilaku. Selain itu, melalui studi meta-analysis, Armitage dan Conner (2001) menemukan kemampuan konstruk kontrol perilaku persepsian untuk memprediksi perilaku, baik secara langsung maupun tidak langsung. Oleh karena itu, penelitian ini menghipotesiskan:

H5: Kontrol perilaku persepsian manajer atas pengungkapan TSP berpengaruh positif terhadap pengungkapan TSP.

Secara menyeluruh, rerangka konseptual penelitian ini disajikan pada Gambar 1.

\section{METODA PENELITIAN}

Penelitian ini menggunakan sampel perusahaan yang tercatat di Bursa Efek Indonesia (BEI) yang bergerak di sektor industri (1) Pertanian; (2) Pertambangan; (3) Industri Dasar dan Kimia; (4) Aneka Industri; dan (5) Industri Barang Konsumsi. Pemilihan sampel menggunakan teknik purposive sampling dengan kriteria (1) perusahaan tercatat di BEI pada tahun 2007 dan 2008, (2) perusahaan yang dimaksud pada poin (1) mempunyai laporan tahunan untuk tahun 2007 dan tahun 2008, dan (3) laporan tahunan yang dimaksud pada poin (2) dapat diakses atau diperoleh dari berbagai sumber, misalnya melalui website $\mathrm{BEI}$, website masing-masing perusahaan, atau Pusat Referensi Pasar Modal di BEI.
Variabel dalam penelitian terdiri atas empat variabel laten dan satu variabel observe. Variabel laten berupa niat mengungkapkan TSP (NIAT MTSP), sikap terhadap pengungkapan TSP (SIKAP PTSP), norma subyektif atas pengungkapan TSP (NORMASubyPTSP), dan kontrol perilaku persepsian atas pengungkapan TSP (KPP PTSP). Variabel $o b$ serve dalam penelitian ini adalah pengungkapan TSP (PTSP). Sumber data penelitian ini terdiri atas data sekunder dan primer. Data sekunder berupa pengungkapan TSP yang diperoleh melalui laporan tahunan perusahaan. Data primer berupa respon tentang keyakinan manajer terhadap pengungkapan TSP yang diperoleh melalui survei kuesioner.

Kuesioner penelitian ini dipersiapkan melalui dua tahap. Pertama, mengidentifikasi dimensi TSP dan cakupan pengungkapannya. Sesuai literatur TSP (misalnya Gray et al. 1995; Hackston dan Milne 1996), dalam penelitian ini diidentifikasi enam isu (dimensi) pengungkapan TSP. Keenam dimensi tersebut meliputi kontribusi perusahaan terhadap halhal berikut ini. 1) Lingkungan, yaitu berbagai aktivitas perusahaan yang dilakukan terutama untuk mengurangi atau mencegah kerusakan lingkungan. 2) Energi, yaitu berbagai aktivitas perusahaan yang dilakukan untuk efisiensi energi. 3) Sumber daya manusia (SDM) perusahaan, yaitu aktivitas perusahaan yang terutama dimaksudkan untuk memberi manfaat (benefit) bagi karyawan perusahaan (sekarang dan yang akan datang). 4) Masyarakat setempat (local community), yaitu aktivitas perusahaan yang terutama ditujukan untuk memberi manfaat bagi kehidupan masyarakat di sekitar area perusahaan atau pabrik. 5) Produk, yaitu aktivitas perusahaan yang mempengaruhi hubungan dengan konsumen atau masyarakat yang timbul dari produk. 6) Aktivitas TSP lainnya, yaitu aktivitas TSP di luar kelima dimensi yang telah disebutkan.

Selanjutnya, mengonstruksi kuesioner untuk mengetahui NIAT MTSP, SIKAP PTSP, dan NORMASuby-PTSP, dan KPP PTSP sesuai kaidah pada TPR. Ukuran setiap variabel penelitian diuraikan berikut ini. 
Tabel 1: Indikator Pengukur NIAT MTSP

\begin{tabular}{|c|c|}
\hline Indikator NIAT MTSP & Penjelasan \\
\hline NM1 - NM4 & $\begin{array}{l}\text { Merupakan indikator pengukur NIAT MTSP untuk aspek kontribusi } \\
\text { perusahaan terhadap lingkungan (empat item kuesioner). }\end{array}$ \\
\hline NM5 - NM7 & $\begin{array}{l}\text { Merupakan indikator pengukur NIAT MTSP untuk aspek kontribusi } \\
\text { perusahaan terhadap energi (tiga item kuesioner). }\end{array}$ \\
\hline NM8 - NM12 & $\begin{array}{l}\text { Merupakan indikator pengukur NIAT MTSP untuk aspek kontribusi } \\
\text { perusahaan terhadap SDM (lima item kuesioner).. }\end{array}$ \\
\hline NM13 & $\begin{array}{l}\text { Merupakan indikator pengukur NIAT MTSP untuk aspek kontribusi } \\
\text { perusahaan terhadap masyarakat setempat ( } 1 \text { item kuesioner). }\end{array}$ \\
\hline NM14 - NM16 & $\begin{array}{l}\text { Merupakan indikator pengukur NIAT MTSP untuk aspek kontribusi } \\
\text { perusahaan terhadap produk (tiga item kuesioner). }\end{array}$ \\
\hline NM17 - NM19 & $\begin{array}{l}\text { Merupakan indikator pengukur NIAT MTSP untuk aspek kontribusi } \\
\text { perusahaan terhadap aktivitas TSP lainnya (tiga item kuesioner). }\end{array}$ \\
\hline
\end{tabular}

$\mathrm{NM}=$ Niat Mengungkapkan

NIAT MTSP diukur dengan mengonstruksi pernyataan 'Saya berniat untuk mengungkapkan pada laporan tahunan tentang aktivitas TSP berikut ini...' Jawaban atas sembilan belas item pengungkapan TSP, yaitu NM1 - NM 19 (lihat Tabel 1) dikonstruksi menggunakan skala Likert 5-poin dengan format jawaban berkisar dari sangat tidak mungkin ke sangat mungkin. Semakin besar skor merefleksi niat yang semakin kuat untuk mengungkapkan TSP.

SIKAP PTSP diukur menggunakan formula: Sikap $\propto \sum \mathrm{k}_{\mathrm{i}} \mathrm{h}_{\mathrm{i}}$. Menurut persamaan tersebut, sikap adalah proporsional secara langsung $(\propto)$ terhadap jumlah dari hasil perkalian antara kekuatan keyakinan perilaku (k) dan evaluasi terhadap hasil (outcome) perilaku (h), untuk i dari 1 ke n (Ajzen 2002). Penelitian ini menggunakan tiga indikator sikap, yaitu SIKAP-Pr, SIKAP-Rm, dan SIKAP-Ps. SIKAP-Pr, SIKAP-Rm, dan SIKAP-Ps menunjukkan kekuatan keyakinan (sangat buruk - sangat baik) responden dan evaluasi (sangat tidak setuju - sangat setuju) tentang manfaat pengungkapan TSP bagi perusahaan, reputasi manajer, dan pasar.

NORMASuby-PTSP diukur menggunakan formula: NormaSubyektif $\propto \sum \mathrm{n}_{\mathrm{i}} \mathrm{p}_{\mathrm{i}}$. Menurut persamaan tersebut, norma subyektif adalah proporsional secara langsung $(\propto)$ terhadap jumlah hasil perkalian antara keyakinan normatif (n) dan tingkat kepatuhan kepada referent ( $\mathrm{p}$ ), untuk i dari 1 ke $\mathrm{n}$. Penelitian ini menggunakan lima indikator norma subyektif, yaitu norma subyektif pemegang saham (NORMASuby-PS), norma subyektif kreditor perusahaan (NORMASuby-Kr), norma subyektif pemerintah (NORMASuby-Pm), norma subyektif lembaga swadaya masyarakat (NORMASuby-LSM), dan norma subyektif konsultan perusahaan (NORMASuby-KP). NORMASuby-PS, NORMASuby-Kr, NORMASuby-Pm, NORMASuby-LSM, dan NORMASuby-KP secara berurutan menunjukkan kekuatan keyakinan (sangat kecil sangat besar) responden terhadap dukungan atau keinginan pemegang saham (PS), kreditor perusahaan $(\mathrm{Kr})$, pemerintah $(\mathrm{Pm})$, lembaga swadaya masyarakat (LSM), dan konsultan perusahaan (KP) untuk mengungkapkan TSP dan tingkat kepatuhan (sangat kecil - sangat besar) responden terhadap kelima pihak (referent) tersebut.

KPP PTSP diukur menggunakan kuesioner yang dikembangkan oleh Weldman (2002) dengan mengganti istilah lingkungan menjadi TSP untuk mengetahui kontrol perilaku persepsian atas pengungkapan TSP. Kuesioner terdiri atas empat pernyataan, yaitu (1) saya mempunyai kontrol atas keputusan untuk mengungkapkan TSP pada laporan tahunan (KPP1), (2) akan sangat mudah bagi saya untuk mengungkapkan TSP pada laporan tahunan (KPP2), (3) kewenangan yang diberikan kepada posisi saya adalah cukup untuk memutuskan pengungkapan TSP pada laporan tahunan (KPP3), dan (4) saya merasa yakin bahwa keahlian, kemampuan, dan kualitas 
pengetahuan yang saya miliki akan sangat membantu dalam pengambilan keputusan pengungkapan TSP pada laporan tahunan (KPP4). Kepada responden diminta menentukan keyakinannya (menggunakan skala Likert 5-poin, dari sangat tidak setuju sampai dengan sangat setuju) terhadap keempat pernyataan tersebut.

Pengungkapan Tanggung Jawab Sosial Perusahaan (PTSP) diukur menggunakan indeks pengungkapan TSP (Indeks PTSP). Indeks PTSP adalah jumlah skor pengungkapan TSP dibagi jumlah aktivitas TSP dikalikan $100 \%$. Jumlah skor pengungkapan TSP adalah jumlah kalimat pengungkapan TSP pada laporan tahunan untuk keenam dimensi pengungkapan TSP sebagaimana telah dikemukakan. Jumlah aktivitas TSP adalah enam, yaitu jumlah dimensi aktivitas TSP yang digunakan dalam penelitian ini.

Persamaan ekonometri untuk menguji hipotesis penelitian ini adalah sebagai berikut.

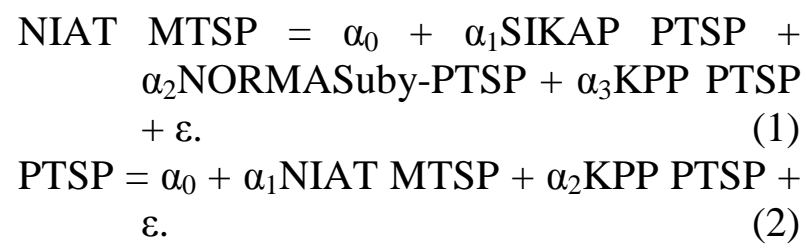

Sebelum dilakukan pengujian hipotesis, terlebih dahulu dilakukan pengujian model pengukuran untuk menilai validitas konstruk dan reliabilitas instrumen. Parameter validitas yang digunakan adalah (1) skor loadings setiap indikator konstruk (rule of thumb > 0,7), (2) skor AVE > 0,5, (3) skor communality $>0,5$, dan (4) redundancy mendekati 1. Indikator dengan skor loadings antara 0,5-0,7 dapat dipertahankan sepanjang nilai AVE > 0,5. Parameter untuk menilai reliabilitas instrumen adalah Cronbachs alpha dan composite reliability. Suatu instrumen penelitian dapat memenuhi kriteria sebagai instrumen yang reliable apabila memiliki Cronbachs alpha > 0,6 dan composite reliability > 0,7. Teknik Partial Least Square (PLS) digunakan untuk mengolah dan menganalisis data.

\section{HASIL DAN PEMBAHASAN}

Perusahaan yang memenuhi kriteria sampel berjumlah 138 perusahaan. Kuesioner dikirim/diserahkan kepada 138 perusahaan tersebut. Tabel 2 menyajikan jumlah sampel penelitian sesuai jumlah respon kuesioner diterima.

Tabel 2: Jumlah Sampel Penelitian

\begin{tabular}{lrr}
\hline \multicolumn{1}{c}{ Keterangan } & Jumlah & Persentase \\
\hline Jumlah kuesioner diserahkan/dikirim & 138 & $100 \%$ \\
Jumlah kuesioner tidak kembali & 102 & \\
Jumlah kuesioner kembali & 36 & \\
Jumlah kuesioner kembali tetapi tidak dapat diolah lebih lanjut & 4 & \\
Jumlah kuesioner kembali dan dapat diolah lebih lanjut & $\underline{32}$ & $\underline{23 \%}$ \\
Jumlah kuesioner kembali dan dapat diolah lebih lanjut berdasarkan sektor & & \\
$\quad$ industri: & 9 & $28 \%$ \\
$\quad$ Aneka Industri & 9 & $28 \%$ \\
$\quad$ Industri Barang Konsumsi & 11 & $35 \%$ \\
$\quad$ Industri Dasar dan Kimia & 2 & $6 \%$ \\
$\quad$ Pertambangan & 1 & $3 \%$ \\
$\quad$ Pertanian & $\underline{32}$ & $\underline{100 \%}$ \\
Jumlah & & \\
Jumlah kuesioner kembali dan dapat diolah lebih lanjut berdasarkan teknik & 7 & $22 \%$ \\
pengumpulannya: & 19 & $59 \%$ \\
$\quad$ Melalui pos & 6 & $19 \%$ \\
$\quad$ Dijemput/diambil langsung & $\underline{\underline{32}}$ & $\underline{\underline{100 \%}}$ \\
$\quad$ Website & & \\
Jumlah & &
\end{tabular}




\section{Statistik Deskriptif}

Statistik deskriptif data penelitian disajikan pada Tabel 3 sampai dengan Tabel 7. Pada Tabel 3, nilai rata-rata SIKAP PTSP berkisar antara 15,78 sampai 17,56 . Pada penelitian ini nilai netral untuk kekuatan keyakinan perilaku dan nilai netral untuk evaluasi terhadap hasil perilaku masing-masing berbobot tiga. Oleh karena sikap merupakan jumlah dari hasil perkalian antara bobot nilai kekuatan keyakinan perilaku dan bobot nilai evaluasi tehadap hasil perilaku, maka nilai netral untuk konstruk SIKAP PTSP adalah sembilan. Artinya jika nilai rata-rata SIKAP PTSP lebih besar dari sembilan, maka responden pada penelitian ini secara umum mempunyai sikap positif terhadap pengungkapan TSP. Melalui Tabel 3 dapat diinterpretasikan kekuatan keyakinan responden terhadap manfaat pengungkapan TSP bagi reputasi manajer cenderung lebih tinggi dibandingkan dengan kekuatan keyakinan terhadap manfaat pengungkapan TSP bagi perusahaan dan pasar. Deviasi standar SIKAPPr lebih kecil dari SIKAP-Rm dan SIKAP-Ps, artinya besaran masing-masing data SIKAP-Pr cenderung lebih mendekati rata-ratanya dibandingkan dengan SIKAP-Rm dan SIKAPPs. Dapat juga dikatakan, variabilitas data SIKAP-Pr relatif lebih rendah dari variabilitas data SIKAP-Rm dan SIKAP-Ps.

Tabel 3: Deskripsi Data Indikator Variabel SIKAP PTSP

\begin{tabular}{lccccc}
\hline \multicolumn{1}{c}{ Indikator SIKAP PTSP } & N & Minimum & Maksimum & Rata-rata & Dev. Standar \\
\hline SIKAP-Pr & 32 & 11 & 22 & 17,16 & 3,575 \\
SIKAP-Rm & 32 & 9 & 25 & 17,56 & 4,016 \\
SIKAP-Ps & 32 & 9 & 24 & 15,78 & 4,101 \\
Valid N (listwise) & 32 & & & & \\
\hline
\end{tabular}

Tabel 4: Deskripsi Data Indikator Variabel NORMASuby-PTSP

\begin{tabular}{lccccc}
\hline \multicolumn{1}{c}{ Indikator NORMASuby-PTSP } & N & Minimum & Maksimum & Rata-rata & Dev. Standar \\
\hline NORMASuby-PS & 32 & 8 & 25 & 16,38 & 5,464 \\
NORMASuby-Kr & 32 & 6 & 25 & 15,28 & 5,612 \\
NORMASuby-Pm & 32 & 9 & 25 & 18,66 & 4,968 \\
NORMASuby-LSM & 32 & 8 & 25 & 16,06 & 5,747 \\
NORMASuby-KP & 32 & 4 & 25 & 14,78 & 5,890 \\
Valid N (listwise) & 32 & & & & \\
\hline
\end{tabular}

Tabel 5: Deskripsi Data Indikator NIAT MTSP Berdasarkan Kategori (Dimensi) Pengungkapan TSP

\begin{tabular}{lccccc}
\hline Indikator NIAT MTSP & $\mathrm{N}$ & Minimum & Maksimum & Rata-rata & Dev. Standar \\
\hline Kontribusi terhadap lingkungan & 4 & 4,12 & 4,59 & 4,4288 & 0,20690 \\
Kontibusi terhadap energy & 3 & 3,75 & 4,53 & 4,0827 & 0,40244 \\
Kontribusi terhadap SDM & 5 & 3,84 & 4,81 & 4,4927 & 0,37876 \\
Kontribusi terhadap masy. setempat & 1 & 4,47 & 4,47 & 4,4680 &. \\
Kontribusi terhadap produk & 3 & 4,22 & 4,59 & 4,4667 & 0,21362 \\
Kontribusi terhadap TSP lainnya & 3 & 4,47 & 4,59 & 4,5493 & 0,07044 \\
Valid N (listwise) & 1 & & & & \\
\hline
\end{tabular}

Tabel 6: Deskripsi Data Indikator Variabel KPP-PTSP

\begin{tabular}{lccccc}
\hline \multicolumn{1}{c}{ Indikator KPP-PTSP } & $\mathrm{N}$ & Minimum & Maksimum & Rata-rata & Dev. Standar \\
\hline KPP1 & 32 & 2 & 5 & 3,78 & 0,870 \\
KPP2 & 32 & 2 & 5 & 3,84 & 0,723 \\
KPP3 & 32 & 3 & 5 & 3,75 & 0,672 \\
KPP4 & 32 & 3 & 5 & 3,97 & 0,595 \\
Valid N (listwise) & 32 & & & & \\
\hline
\end{tabular}

KPP = Kontrol Perilaku Persepsian 
Pada Tabel 4, nilai rata-rata NORMASuby-PTSP berkisar antara 14,78 sampai 18,66. Pada penelitian ini nilai netral untuk kekuatan keyakinan dukungan dari referent (PS, Kr, Pm, LSM, dam KP) dan nilai netral untuk tingkat kepatuhan terhadap referent masing-masing berbobot tiga. Oleh karena norma subyektif merupakan jumlah dari hasil perkalian antara bobot nilai kekuatan keyakinan dukungan dari referent dan bobot nilai tingkat kepatuhan terhadap referent, maka nilai netral untuk konstruk NORMASuby-PTSP adalah sembilan. Artinya jika nilai rata-rata NORMASuby-PTSP lebih besar dari 9, maka dapat diartikan responden pada penelitian ini secara umum mempunyai norma subyektif positif terhadap pengungkapan TSP. Melalui Tabel 4 dapat diinterpretasikan pemerintah merupakan referent yang cenderung lebih diutamakan dan lebih dipatuhi oleh responden dibandingkan dengan referent lainnya (pemegang saham, LSM, kreditor, dan konsultan perusahaan). Deviasi standar untuk NORMASuby-Pm $(4,968)$ paling rendah dibandingkan dengan indikator lain untuk NORMASuby-PTSP. Artinya variabilitas jawaban responden untuk NORMASuby-Pm relatif lebih rendah dari variabilitas respon untuk indikator lainnya dalam NORMASuby-PTSP.

Pada Tabel 5, secara rata-rata, niat terbesar adalah niat untuk mengungkapkan kontribusi perusahaan terhadap TSP lainnya (ratarata 4,549) yang meliputi: (1) niat untuk mengungkapkan kesesuaian operasi perusahaan dengan undang-undang atau regulasi lain tentang lingkungan dan/atau energi; (2) niat untuk mengungkapkan usaha perusahaan dalam memperoleh penghargaan/sertifikasi berkaitan dengan program kebijakan lingkungan dan/atau energi; dan (3) niat untuk mengungkapkan usaha perusahaan dalam memperoleh penghargaan/sertifikasi berkaitan dengan program kebijakan kualitas produk.
Sebaliknya, secara rata-rata, niat terkecil adalah niat untuk mengungkapkan TSP pada aspek kontribusi perusahaan terhadap energi (rata-rata 4,0827).

Pada Tabel 6, nilai rata-rata KPP-PTSP berkisar antara 3,75 sampai 3,97. Pada penelitian ini nilai netral untuk KPP-PTSP berbobot tiga. Oleh karena nilai rata-rata lebih dari tiga, maka dapat diartikan responden pada penelitian ini secara umum mempunyai kontrol perilaku persepsian yang positif atas pengungkapan TSP. Melalui Tabel 6, bobot nilai rata-rata tertinggi adalah KPP4 $(3,97)$. Hal ini menunjukkan faktor keahlian, kemampuan, dan kualitas pengetahuan responden dalam mengungkapkan TSP secara umum cenderung lebih menentukan tingkat kemudahan responden dalam mengungkapkan TSP dibandingkan dengan faktor lainnya. Deviasi standar KPP4 $(0,595)$ lebih rendah dari KPP1 $(0,870)$, KPP2 $(0,723)$, dan KPP3 $(0,672)$. Hal ini menunjukkan variabilitas data respon untuk KPP4 lebih rendah dari KPP1, KPP2, dan KPP3.

Melalui Tabel 7, jumlah minimum pengungkapan TSP adalah 2 (dua) kalimat, sedangkan jumlah maksimum pengungkapan adalah 88 (delapan puluh delapan) kalimat. Indeks pengungkapan TSP minimum adalah $33 \%$ dan maksimum $1.467 \%$. Berdasarkan analisis, rata-rata tertinggi jumlah kalimat pengungkapan TSP terdapat pada sektor industri pertambangan (rata-rata 65 kalimat), disusul (secara berturut-turut) sektor industri dasar dan kimia (rata-rata 24 kalimat), aneka industri (rata-rata 21 kalimat), industri barang konsumsi (rata-rata 19 kalimat), dan pertanian (rata-rata 8 kalimat). Hal ini dapat dipahami mengingat pertambangan merupakan sektor industri yang dianggap paling sensitif terhadap masalah-masalah lingkungan dan sering menjadi pusat perhatian Lembaga Swadaya Masyarakat yang bergerak di bidang pelestarian lingkungan.

Tabel 7: Deskripsi Data Variabel PTSP

\begin{tabular}{lrrrrr}
\hline \multicolumn{1}{c}{ Variabel } & N & Minimum & Maksimum & Rata-rata & Dev. Standar \\
\hline PTSP & 32 & 2 & 88 & 23,78 & 19,289 \\
Indeks PTSP (\%) & 32 & 33 & 1467 & 396,38 & 321,554 \\
Valid N (listwise) & 32 & & & & \\
\hline
\end{tabular}


Jumlah kalimat pengungkapan TSP sebagaimana telah diuraikan menunjukkan adanya variasi antarperusahaan. Hal ini mencerminkan pengungkapan TSP sampai dengan pembuatan laporan tahunan untuk tahun 2007 masih bersifat sukarela.

\section{Hasil Pengujian Bias Tidak Merespon}

Untuk menguji bias tidak merespon, respon atas kuesioner dikelompokkan ke dalam dua kelompok, yaitu respon tidak terlambat dan respon terlambat. Respon dikategorikan tidak terlambat apabila respon tersebut diterima pada tahun 2009, yaitu sesuai dengan tahun pengiriman/penyerahan kuesioner pertama kali, sedangkan respon terlambat adalah respon yang diterima setelah tahun 2009 .

Berdasarkan uji beda $t$-test nilai probabilitas ( $p$-value) untuk setiap konstruk $>0,05$. Artinya tidak terdapat perbedaan signifikan antara rata-rata respon kuesioner tidak terlambat dan terlambat. Dengan demikian data penelitian ini bebas dari bias tidak merespon.

\section{Hasil Pengujian Model Pengukuran}

Berdasarkan hasil pengujian model pengukuran menunjukkan terdapat delapan dari sembilan belas indikator NIAT MTSP (yaitu NM3, NM4, NM5, NM6, NM7, NM11, NM12, dan NM15) yang tidak memenuhi syarat sehingga harus dibuang dari model, sedangkan seluruh indikator SIKAP PTSP, NORMASuby-PTSP, dan KPP PTSP, menunjukkan indikator yang valid. Tabel 8 dan 9 menyajikan hasil pengujian model pengukuran setelah membuang beberapa indikator tidak valid untuk konstruk NIAT MTSP.

Pada Tabel 8, skor loadings indikator setiap konstruk adalah 0,64 - 0,84 (untuk NIAT MTSP); 0,67 - 0,98 (untuk NORMASubyPTSP); dan 0,60 - 0,95 (untuk SIKAP PTSP). Skor AVE dan communality pada setiap konstruk $>0,5$ (lihat Tabel 9). Dengan demikian, seluruh indikator dalam penelitian ini telah memenuhi syarat sebagai konstruk yang valid.

Tabel 8: Skor Loadings: Hasil Pengujian Model Pengukuran

\begin{tabular}{|c|c|c|c|c|c|}
\hline Indikator & KPP & $\begin{array}{l}\text { NIAT } \\
\text { MTSP }\end{array}$ & $\begin{array}{c}\text { NORSUB } \\
\text { Y-PTSP }\end{array}$ & PTSP & $\begin{array}{l}\text { SIKAP } \\
\text { PTSP }\end{array}$ \\
\hline KPP1 & 0,778355 & & & & \\
\hline KPP2 & 0,741541 & & & & \\
\hline KPP3 & 0,846304 & & & & \\
\hline KPP4 & 0,864321 & & & & \\
\hline NM1 & & 0,637642 & & & \\
\hline NM10 & & 0,822190 & & & \\
\hline NM13 & & 0,701553 & & & \\
\hline NM14 & & 0,640507 & & & \\
\hline NM16 & & 0,797832 & & & \\
\hline NM17 & & 0,771758 & & & \\
\hline NM18 & & 0,675657 & & & \\
\hline NM19 & & 0,639951 & & & \\
\hline NM2 & & 0,646547 & & & \\
\hline NM8 & & 0,843978 & & & \\
\hline NM9 & & 0,673336 & & & \\
\hline NORMASuby-KP & & & 0,794318 & & \\
\hline NORMASuby-Kr & & & 0,824749 & & \\
\hline NORMASuby-LSM & & & 0,818956 & & \\
\hline NORMASuby-PS & & & 0,669526 & & \\
\hline NORMASuby-Pm & & & 0,751842 & & \\
\hline PTSP & & & & 1,000000 & \\
\hline SIKAP-Pr & & & & & 0,732054 \\
\hline SIKAP-Ps & & & & & 0,833430 \\
\hline SIKAP-Rm & & & & & 0,598109 \\
\hline
\end{tabular}


Tabel 9: Kriteria Kualitas: Hasil Pengujian Model Pengukuran

\begin{tabular}{lcccccc}
\hline & AVE & $\begin{array}{c}\text { Composite } \\
\text { Reliability }\end{array}$ & R Square & $\begin{array}{c}\text { Cronbachs } \\
\text { Alpha }\end{array}$ & Communality & Redundancy \\
\hline KPP PTSP & 0,702561 & 0,921419 & & 0,897236 & 0,702560 & \\
NIAT MTSP & 0,528924 & 0,930142 & 0,397333 & 0,917230 & 0,528924 & 0,105708 \\
NORMASuby-PTSP & 0,659363 & 0,919742 & & 0,893254 & 0,659363 & \\
PTSP & 1,000000 & 1,000000 & 0,172543 & 1,000000 & 1,000000 & 0,095444 \\
SIKAP PTSP & 0,623616 & 0,865723 & & 0,793909 & 0,623616 & \\
\hline
\end{tabular}

Suatu instrumen penelitian dapat memenuhi kriteria sebagai instrumen yang reliable apabila memiliki Cronbachs alpha > 0,6 dan composite reliability > 0,7. Berdasarkan Tabel 9, Cronbach alpha dan composite reliability untuk masing-masing konstruk memiliki skor > 0,6 dan $>0,7$. Artinya instrumen penelitian ini telah memenuhi syarat sebagai instrumen yang reliable.

\section{Hasil Pengujian Model Struktural}

Pada SmartPLS, model struktural dievaluasi berdasarkan nilai R-square ${ }^{3}$ untuk variabel dependen dan nilai koefisien jalur $(\beta)$ untuk variabel independen, kemudian dinilai signifikansinya berdasarkan nilai t-statistik setiap jalur (Hartono dan Abdillah 2009). Pengujian model struktural dilakukan melalui proses bootstrapping. Nilai koefisien jalur disajikan pada Tabel 10.

Berdasarkan Tabel 9, R-square untuk variabel dependen NIAT MTSP sebesar 0,3973 (moderat). ${ }^{4}$ Hal ini dapat diinterpretasikan bahwa variabilitas konstruk NIAT MTSP dapat dijelaskan oleh konstruk SIKAP PTSP, NORMASuby-PTSP, dan KPP-PTSP sebesar $40 \%$, sisanya $(60 \%)$ dijelaskan oleh variabel lain yang tidak diteliti (variabel di luar model penelitian). Nilai R-square untuk variabel dependen PTSP sebesar 0,1725 (lemah). Artinya variabilitas konstruk PTSP dapat dijelaskan oleh konstruk NIAT MTSP, KPP-PTSP sebesar $17 \%$, sisanya (83\%) dijelaskan oleh variabel lain di luar model. Selanjutnya, hipotesis penelitian akan di-

\footnotetext{
${ }^{3}$ Menunjukkan goodness-of-fit model.

4 Menurut Chin (1998) sebagaimana dikutip dalam Ghozali (2008), $\mathrm{R}^{2}$ sebesar 0,67; 0,33; dan 0,19 mengindikasikan bahwa model adalah "baik"; "moderat'; dan "lemah".
}

dukung apabila koefisien $\beta$ untuk setiap konstruk bernilai positif dan nilai t-statistik lebih besar dari nilai t-tabel (nilai t-tabel signifikansi $5 \%=1,64)$. Nilai koefisien jalur $(\beta)$ dan nilai t-statistik disajikan pada Tabel 10 . Berikut ini diuraikan hasil pengujian hipotesis berdasarkan Tabel 10.

H1 menyatakan, 'sikap manajer atas pengungkapan TSP berpengaruh positif terhadap niatnya untuk mengungkapkan TSP.' Berdasarkan Tabel 10, nilai koefisien $\beta$ untuk SIKAP PTSP ke NIAT MTSP sebesar 0,300053 dan nilai t-statistik sebesar 3,017971 menunjukkan SIKAP PTSP berpengaruh positif dan signifikan secara statistik terhadap NIAT MTSP. Dengan demikian, penelitian ini mendukung hipotesis yang menyatakan 'sikap manajer atas pengungkapan TSP berpengaruh positif terhadap niatnya untuk mengungkapkan TSP.' Artinya semakin positif sikap individu terhadap pengungkapan TSP semakin besar niat individu tersebut untuk mengungkapkan TSP.

H2 menyatakan, "norma subyektif manajer atas pengungkapan TSP berpengaruh positif terhadap niatnya untuk mengungkapkan TSP.' Berdasarkan Tabel 10, nilai koefisien $\beta$ untuk NORMASuby-PTSP ke NIAT MTSP sebesar 0,205989 dan nilai t-statistik sebesar 2,326646 menunjukkan NORMASuby-PTSP berpengaruh positif dan signifikan secara statistik terhadap NIAT MTSP. Dengan demikian, penelitian ini mendukung hipotesis yang menyatakan 'norma subyektif manajer atas pengungkapan TSP berpengaruh positif terhadap niatnya untuk mengungkapkan TSP.' Artinya semakin kuat norma subyektif individu atas pengungkapan TSP, semakin besar niat individu tersebut untuk mengungkapkan TSP. 
Tabel 10: Koefisien Jalur: Hasil Pengujian Model Stuktural

\begin{tabular}{lccccc}
\hline & $\begin{array}{c}\text { Original } \\
\text { Sample }(\mathrm{O})\end{array}$ & $\begin{array}{c}\text { Sample } \\
\text { Mean (M) }\end{array}$ & $\begin{array}{c}\text { Standard } \\
\text { Deviation } \\
(\text { STDEV) }\end{array}$ & $\begin{array}{c}\text { Standard } \\
\text { Error } \\
(\text { STERR })\end{array}$ & $\begin{array}{c}\text { T Statistics } \\
(\mid \text { O/STERR })\end{array}$ \\
\hline KPP PTSP $\rightarrow$ NIAT MTSP & 0,303811 & 0,319519 & 0,077105 & 0,077105 & 3,940212 \\
KPP PTSP $\rightarrow$ PTSP & 0,202689 & 0,205099 & 0,084637 & 0,084637 & 2,394802 \\
NIAT MTSP $\rightarrow$ PTSP & 0,277668 & 0,287022 & 0,087522 & 0,087522 & 3,172550 \\
NORMASuby-PTSP $\rightarrow$ NIAT MTSP & 0,205989 & 0,204900 & 0,088535 & 0,088535 & 2,326646 \\
SIKAP PTSP $\rightarrow$ NIAT MTSP & 0,300053 & 0,297316 & 0,099422 & 0,099422 & 3,017971 \\
\hline
\end{tabular}

H3 menyatakan ' $k$ ontrol perilaku persepsian manajer atas pengungkapan TSP berpengaruh positif terhadap niatnya untuk mengungkapkan TSP.' Berdasarkan Tabel 10, nilai koefisien $\beta$ untuk KPP-PTSP ke NIAT MTSP sebesar 0,303811 dan nilai t-statistik sebesar 3,940212 menunjukkan KPP-PTSP berpengaruh positif dan signifikan secara statistik terhadap NIAT MTSP. Dengan demikian, penelitian ini mendukung hipotesis yang menyatakan 'kontrol perilaku persepsian manajer atas pengungkapan TSP berpengaruh positif terhadap niatnya untuk mengungkapkan TSP.' Semakin tinggi kontrol perilaku persepsian atas pengungkapan TSP, semakin besar niat untuk mengungkapkan TSP.

Berdasarkan hasil pengujian $\mathrm{H} 1$ sampai dengan $H 3$, koefisien $\beta$ untuk SIKAP PTSP, NORMASuby-PTSP, dan KPP-PTSP masing-masing (secara berturut-turut) sebesar 0,300053; 0,205989; dan 0,303811. Artinya norma subyektif merupakan komponen paling lemah untuk menjelaskan niat perilaku. Hasil penelitian ini sekaligus mengonfirmasi penelitian sebelumnya yang menyimpulkan norma subyektif sebagai komponen paling lemah untuk menjelaskan niat perilaku (misalnya, Sheppard et al. 1988 dan Van den Putte, 1991 dalam Armitage dan Conner 2001). Metaanalitic yang dilakukan oleh Armitage dan Conner (2001) juga memberikan hasil yang sama. Dalam kaitan ini Ajzen (1991: 188) menyatakan sebagai berikut.

"The relative importance of attitude, subjectives norm, and perceived behavioral control in the prediction of intention is expected to vary across behaviours and situations. That is, in situations where (for example) attitudes are strong, or where normative influences are powerful, perceived behavioral control may be less predictive of intentions."

H4 menyatakan, 'niat manajer untuk mengungkapkan TSP berpengaruh positif terhadap pengungkapan TSP.' Berdasarkan Tabel 10, nilai koefisien $\beta$ untuk NIAT MTSP ke PTSP sebesar 0,277668 dan nilai t-statistik sebesar 3,172550 menunjukkan NIAT MTSP berpengaruh positif dan signifikan secara statistik terhadap PTSP. Dengan demikian penelitian ini mendukung hipotesis yang menyatakan 'niat manajer untuk mengungkapkan TSP berpengaruh positif terhadap pengungkapan TSP.' Semakin besar niat untuk mengungkapkan TSP, semakin luas pengungkapan TSP yang dilakukannya.

H5 menyatakan, 'kontrol perilaku persepsian manajer atas pengungkapan TSP berpengaruh positif terhadap pengungkapan TSP.' Berdasarkan Tabel 10, nilai koefisien $\beta$ untuk KPP-PTSP ke PTSP sebesar 0,202689 dan nilai t-statistik sebesar 2,394802 menunjukkan KPP-PTSP berpengaruh positif dan signifikan secara statistik terhadap PTSP. Dengan demikian penelitian ini mendukung hipotesis yang menyatakan 'kontrol perilaku persepsian manajer atas pengungkapan TSP berpengaruh positif terhadap pengungkapan TSP.' Semakin besar kontrol perilaku persepsian manajer niat untuk mengungkapkan TSP, semakin luas pengungkapan TSP yang dilakukannya. Hasil penelitian ini sama dengan hasil penelitian Armitage dan Conner (2001) yang menemukan kontrol perilaku persepsian secara independen mempunyai kemampuan prediksi yang kuat terhadap niat perilaku dan perilaku aktual. 


\section{SIMPULAN}

Secara menyeluruh, hasil penelitian ini mendukung hipotesis teori perilaku rencanaan. Menurut teori perilaku rencanaan, perilaku dipengaruhi oleh niat untuk melakukan perilaku (niat perilaku) dan kontrol perilaku persepsian. Selanjutnya, niat perilaku ditentukan oleh tiga faktor, yaitu sikap terhadap perilaku, norma subyektif atas perilaku, dan kontrol perilaku persepsian. Penelitian ini dapat membuktikan perilaku manajer dalam mengungkapkan TSP dipengaruhi oleh niatnya untuk mengungkapkan TSP dan kontrol perilaku persepsiannya atas pengungkapan TSP. Selanjutnya, niat manajer untuk mengungkapkan TSP dipengaruhi oleh sikap manajer terhadap pengungkapan TSP, norma subyektif manajer atas pengungkapan TSP, dan kontrol perilaku persepsiannya atas pengungkapan TSP.

Penelitian ini juga mampu membuktikan, di antara ketiga komponen niat perilaku, norma subyektif merupakan komponen paling lemah untuk menjelaskan niat perilaku. Temuan ini memperkuat temuan penelitian sebelumnya yang menggunakan teori perilaku rencanaan sebagai basis teori (Armitage dan Conner 2001).

Penelitian ini menemukan variasi pengungkapan TSP antarperusahaan. Oleh karena itu, pemerintah selaku pembuat regulasi semestinya mengatur secara jelas tentang dimensi atau lingkup TSP, termasuk kejelasan definisi TSP. Hal ini diperlukan supaya tidak menimbulkan kerancuan dalam praktik pengungkapan TSP. Dalam hal pelaporan, badan pembuat regulasi pelaporan keuangan untuk perusahaan terbuka semestinya mengatur tentang standar pengungkapan TSP, termasuk lingkup pengungkapannya. Standardisasi pengungkapan diperlukan untuk mengurangi variasi pengungkapan TSP, sehingga akan mempermudah publik dalam menilai TSP.

Penelitian ini membuktikan pemegang saham, kreditor, pemerintah, LSM, dan konsultan perusahaan mempengaruhi manajer dalam mengungkapkan TSP. Dengan demikian, jika pengungkapannya merupakan suatu kewajiban, maka pemerintah harus menyosia- lisasikan kebijakan TSP secara intensif, bukan hanya kepada manajer, tetapi juga kepada pihak-pihak lain yang berkepentingan dengan perusahaan.

Penelitia ini tidak melibatkan variabel lain yang diduga mempengaruhi perilaku, misalnya self-efficacy Menurut Bandura (1982), self-efficacy merupakan variabel penting bagi perubahan perilaku karena menentukan inisiasi perilaku. Meskipun menurut Ajzen (1991) KPP merupakan konstruk yang compatible dengan konstruk self-efficacy, namun, Armitage dan Conner (2001) menyatakan kontrol dan self-efficacy merupakan dua konsep yang sangat berbeda. Self-efficacy lebih menitikberatkan persepsi kognitif atas kontrol yang didasarkan pada faktor-faktor kontrol internal, sedangkan KPP bersifat lebih umum, mencakup faktor-faktor eksternal. Adanya perbedaan antara KPP dan selfefficacy membuka peluang untuk memperluas penelitian ini dengan melibatkan self-efficacy sebagai determinan pengungkapan TSP di Indonesia.

\section{DAFTAR REFERENSI}

Abbott, W. F., dan R. J. Monsen. 1979. On the measurement of corporate social responsibility: Self-reported disclosure as a method of measuring corporate social involvement. Academy of Management Journal 22 (3): 501-515.

Ajzen, I. 1985. From intention to actions: A theory of planned behavior. Dalam J. Kuhl dan J. Beckman (Editor). Action control: From cognition to Behavior. Berlin: Springer-Verlag.

Ajzen, I. 1991. The theory of planned behavior. Organizational Behavior and Human Decision Processes 50 (2): 179-211.

Ajzen, I. 2002. Constructing a TpB questionnaire: Conseptual and methodological consideations. Diambil dari www.people.umass.edu/ajzen/pdf

Armitage, C. J., dan M. Conner. 2001. Efficacy of the theory of planned 
behavior: A meta-analytic review. British Journal of Social Psychology 40: 471-499.

Bandura, A. 1982. Self-efficacy mechanism in human agency. American Psychologist 32 (2): $122-47$.

Belkaoui, A., dan P. G. Karpik. 1989. Determinant of the corporate dimension to disclose social information. Accounting, Auditing and Accountability Journal 2 (1): 36-51.

Carpenter, T. D., dan J. L. Reimers. 2005. Unethical and fraudulent financial reporting: Applying the theory of planned behavior. Journal of Business Ethics 60 (2): 115-129.

Epstein, M. J., dan M. Freedman. 1994. Social disclosure and individual investor. Accounting, Auditing \& Accountability Journal 7 (4): 94-109.

Fishbein, M., dan I. Ajzen. 1975. Belief, attitude, intention, and behavior: An introduction to theory and research. Reading, MA: Addison-Wesley.

Gray, R. 1992. Accounting and environmentalism: An exploration of the challenge of gently accounting for accountability, transparancy and sustainability. Accounting, Organization and Society 17 (5): 399-425.

Gray, R., R. Kouhy, dan S. Lavers. 1995. Constructing a research database of social and environmental reporting by UK companies: A methodological note. Accounting, Auditing and Accountability Journal 8 (2): 78-101.

Hackston, D., dan M. J. Milne. 1996. Some determinants of social and environmental disclosures in New Zealand companies. Accounting, Auditing and Accountability Journal 9 (1): 77-108.

Hanno, D. M., dan G. R. Violette. 1996. An analysis of moral and social influences on taxpayer behavior. Behavioral Research in Accounting 8: 57-75.
Hartono, J., dan W. Abdillah. 2009. Konsep dan aplikasi PLS untuk penelitian empiris. Yogyakarta: BPFE UGM.

Kent, P., dan C. Chan. 2003. Application of stakeholder theory to the quantity and quality of Australian voluntary corporate environmental disclosure. Diambil dari http://papers.ssrn.com/sol3/abstract_id $=447901$.

Mangos, N. C., dan N. R. Lewis. 1995. A socio-economic paradigm for analysing managers' accounting choice behavior. Accounting, Auditing \& Accountability Journal 8 (1): 38-62.

Nurofik. 2013. Pengaruh sikap dan norma subyektif pada pengungkapan tanggung jawab sosial perusahaan. Jurnal Akuntansi dan Manajemen 24 (1): 333.

O'Dwyer, B. 2002. Managerial perceptions of corporate social disclosure: An Irish story. Accounting, Auditing \& Accountability Journal 15 (3): 406-436.

Patten, D. M. 2002. The relation between environmental performance and environmental disclosure: A research note. Accounting, Organization and Society 27.

Weldman, S. M. 2002. A behavioral model of decisions to accrue and disclose environmental liabilities. Diambil dari http://proquest.umi.com/

Wiseman, J. 1982. An evaluation of environmental disclosure made in corporate annual reports. Accounting, Organization and Society 7: 553-563. 